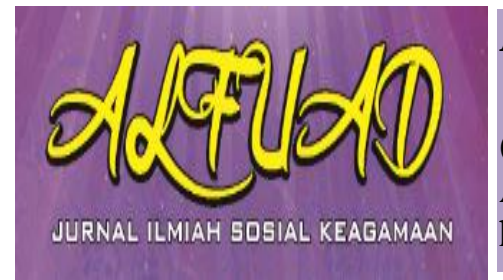

ALFUAD JOURNAL, 5 (2), 2021,(51-61)

(E-ISSN 2714-7606 P-ISSN 2614-4786 )

Available online at

http://ecampus.iainbatusangkar.ac.id/ojs/index.php/alfuad

\title{
Gender Correlation Between Compliance and The Health Protocol in The New Normal Era (The Case on Students in Pekanbaru)
}

\section{Tantri Puspita Yazid*) \\ Universitas Riau, Indonesia \\ E-mail: tantri.yazid@lecturer.unri.ac.id \\ Irwan Iskandar \\ Universitas Riau, Indonesia \\ E-mail: irwan.iskandar@lecturer.unri.ac.id}

\section{Salsabila}

Universitas Riau, Indonesia

E-mail: salsabila1335@student.unri.ac.id

\section{Oktri Permata Lani}

Institut Agama Islam Negeri Batusangkar, Indonesia

E-mail:

oktripermatalani@iainbatusangkar.ac.id

*) Corersponding Author

\begin{abstract}
Facing Covid-19, the government responded with a new normal policy. The public must implement the $5 \mathrm{M}$ health protocol to break the chain of the spread of Covid-19, such as wearing masks, washing hands, maintaining distance, staying away from crowds, and limiting mobility. Through the policy, a compliance action can be investigated. speaking about gender, gender differences seem to influence the health behavior of men and women. According to White, gender is a description of the behavior patterns of men or women which recognized in social life. This study aimed to determine the correlation between gender and compliance with health protocols in the New Normal Era. The population in this study were all students studying at the top 5 universities in Riau Province using the Propionate Stratified Random Sampling technique. The method used is a quantitative method with data collection techniques using questionnaires and observation. In this study using construct validity (construct validity). Testing the validity of this research instrument was carried out with the help of the SPSS 25 application/software and using the Pearson bivariate technique. Meanwhile, the instrument reliability test in this study used the Cronbach Alpha Formula technique and the SPSS 25 in windows program. The data were analyzed using the SPSS Spearman's Rank test, which states the correlation between $X$ and $Y$ variables. The results obtained by this study indicate a significant correlation between the Gender variable and the Health Protocol Compliance variable.
\end{abstract}

Keywords: New Normal Era, Gender, Complience, Health Protocol

\section{INTRODUCTION}

In 2019, the world was shocked by the news of a new virus originating from Wuhan, China's Hubei province. This virus is known as the Covid-19 Virus or Coronavirus Disease 2019, which is an infectious disease caused by Severe Acute Respiratory Syndrome Coronavirus 2 (SARS-CoV-2) and is a new type of coronavirus that previously has not been identified in humans. Common signs and symptoms of Covid-19 infection include symptoms of acute respiratory distress such as fever, cough, and shortness of breath. The average incubation period is 56 days, with the longest incubation period being 14 days. In severe cases of Covid19 , it can cause pneumonia, acute respiratory syndrome, kidney failure, and even death (Kemenkes RI, 2020). 
The World Health Organization (WHO), on March 11, 2020, stated that Covid-19 is a pandemic because it has spread to a large geographic area with a high prevalence. Current epidemiological and virological studies prove that Covid-19 is mainly transmitted from symptomatic people to other people close through droplets. Droplets are water-filled particles with a diameter of $>5-10 \mathrm{~m}$. Droplet transmission occurs when a person is at a close distance (within 1 meter) with someone who has respiratory symptoms (eg, coughing or sneezing) so that droplets are at risk of contracting the mucosa (mouth and nose) or conjunctiva (eyes). Transmission can also occur through objects and surfaces contaminated with droplets around an infected person. Therefore, the transmission of the Covid19 virus can occur through direct contact with an infected person and indirect contact with surfaces or objects used on an infected person (for example, a stethoscope or thermometer).

Covid-19 transmission can happen anywhere. At home, on trips, at work, places of worship, tourist attractions, or other places where people interact socially. The potential for accumulation of particles suspected to contain the SARS-CoV-2 (Covid-19) virus is very high in public facilities with a relatively large population density. In a room with many people, it is considered that the stability of the SARSCoV-2 virus is high, so the process of transmitting the virus to healthy people can occur very quickly (Anggreni \& Safitri, 2020).

On June 1, 2020, the Indonesian government set a new order to deal with Covid-19 with a new normal policy. New normal is a change in lifestyle with a new order and adaptation of habits so that people can be productive and avoid the transmission of Covid-19 (Kemenkes RI, 2020). The public must implement the $5 \mathrm{M}$ health protocol in order to break the chain of the spread of Covid-19, such as wearing masks, washing hands, maintaining distance, staying away from crowds and limiting mobility. Society must adapt to this era so that the wheel of life continues.

The new social life can be carried out after indicating a decrease in the spread curve of the Covid-19 number. The current number of indicators for handling COVID19 in Indonesia continues to show improvement. As of September 26, 2021, the national daily confirmed cases were 1,760 cases or decreased by $96.9 \%$ from the peak on July 15, 2021. On the other hand, the active federal cases reached 42,769 (as of September 26, 2021), or decreased to $92,6 \%$ of peak active cases on July 24, 2021. The effective reproduction rate $(\mathrm{Rt})$ also continues to decline. In some areas, it is below one $(<1)$ 
which means that the rate of transmission of COVID-19 has been controlled; however, we must remain vigilant by complying with the health protocol (covid19.go.id, 2021).

The results of the recap of data from the Riau Provincial Health Office, from March 3, 2020, to September 29, 2021, show data on the distribution of 115,961 suspects and 127.319 confirmed cases of Covid-19 (corona.riau.go.id, 2021). Covid 19 in Riau is also sloping. Head of the Riau Health Office, Mimi Yuliana Nazir, explained that the decline in cases could not be separated from the increasing enthusiasm of the community to be vaccinated and the community's discipline in implementing health protocols (kompas.com, 2021). Compliance is a positive behavior shown by the community when implementing a health protocol system.

Meanwhile, Wulandari (Santi et al., 2021) explains that non-compliance is the extent to which a person's and/or caregiver's behavior conforms to some extent with the health promotion plan or treatment plan agreed between the person (or care provider) and the health care professional. A survey conducted during 714 September 2020 that the lowest level of compliance by age occurred at 17-30 years. Perceptions about the possibility of contracting Covid-19 is seen from the survey results as many as $16.9 \%$ of male and $17 \%$ of female respondents who stated that they were very unlikely and unlikely to be infected with Covid-19.

Head of BPS Suhariyanto also detailed the women are much more compliant with health protocols than men. As many as 94.8 percent of women are more obedient to using masks, 88.5 percent of men. For hand washing, the compliance rate for women is 80.01 percent, for men 69.5 percent, and social distancing for women is 77.5 percent, for men 68.7 percent (cnnindonesia.com, 2020). Based on the $2008 \mathrm{KBBI}$, social demography studying the composition and development of the population, or an overview of demography, from the socio-political and demographic fields. One of the sociodemographic factors, namely gender, plays a role in health determinants, including roles, responsibilities, characteristics, and attributes between men and women who are socially constructed called gender, WHO in (Santi et al., 2021).

The new social life can be carried out after indicating a decrease in the spread curve of the Covid-19 number. The current number of indicators for hand ling COVID19 in Indonesia continues to show improvement. As of September 26, 2021, the national daily confirmed cases were 1,760 cases or decreased by $96.9 \%$ from the peak on July 15, 2021. On the other 
hand, the active federal cases reached 42,769 (as of September 26, 2021), or decreased to $92,6 \%$ of peak active cases on July 24, 2021. The effective reproduction rate $(\mathrm{Rt})$ also continues to decline. In some areas, it is below one $(<1)$ which means that the rate of transmission of COVID-19 has been controlled; however, we must remain vigilant by complying with the health protocol (covid19.go.id, 2021).

The results of the recap of data from the Riau Provincial Health Office, from March 3, 2020, to September 29, 2021, show data on the distribution of 115,961 suspects and 127.319 confirmed cases of Covid-19 (corona.riau.go.id, 2021). Covid 19 in Riau is also sloping. Head of the Riau Health Office, Mimi Yuliana Nazir, explained that the decline in cases could not be separated from the increasing enthusiasm of the community to be vaccinated and the community's discipline in implementing health protocols (kompas.com, 2021). Compliance is a positive behavior shown by the community when implementing a health protocol system.

Meanwhile, Wulandari (Santi et al., 2021) explains that non-compliance is the extent to which a person's and/or caregiver's behavior conforms to some extent with the health promotion plan or treatment plan agreed between the person (or care provider) and the health care professional. A survey conducted during 714 September 2020 that the lowest level of compliance by age occurred at 17-30 years. Perceptions about the possibility of contracting Covid-19 is seen from the survey results as many as $16.9 \%$ of male and $17 \%$ of female respondents who stated that they were very unlikely and unlikely to be infected with Covid-19.

Head of BPS Suhariyanto also detailed the women are much more compliant with health protocols than men. As many as 94.8 percent of women are more obedient to using masks, 88.5 percent of men. For hand washing, the compliance rate for women is 80.01 percent, for men 69.5 percent, and social distancing for women is 77.5 percent, for men 68.7 percent (cnnindonesia.com, 2020). Based on the $2008 \mathrm{KBBI}$, social demography studying the composition and development of the population, or an overview of demography, from the socio-political and demographic fields. One of the sociodemographic factors, namely gender, plays a role in health determinants, including roles, responsibilities, characteristics, and attributes between men and women who are socially constructed called gender, WHO in (Santi et al., 2021).

Gender differences seem to influence the health behavior of men and women. According to White, gender is a 
description of the behavior patterns of men or women recognized in social life. Lippa said that men are aggressive, arrogant, competitive, rude, cruel, dominant, independent, and unemotional, while women are more affectionate, anxious, loving, dependent, emotional, gentle, sensitive, and submissive. The personality possessed by women seems to make women more concerned with health than men (Tambuwun et al., 2021).

Talking about gender, most people in the world, traditionally, conceptualize women's gender role, which is not the same as the gender role of men. When women have the biological physics to give birth and breastfeed, women are viewed by the female brain structure that tends to use emotion rather than logicy; women in most societies get gender roles related to household interests that are more narrowly screwed, such as caring for children, cleaning home and cooking. In contrast, men do not have biological tools like women. Men's bodies are more muscular and robust than women's. When viewed from the arrangement of their brains, men tend to prefer to use logic rather than emotions. The concept of male gender roles in most societies is to do something identical to social activities outside the home and work to earn a living for the family.
The correlation between gender and behavior in complying with health protocols is interesting for further research on students in Pekanbaru. This study uses the perspective of attribution theory which provides a framework for understanding how individuals interpret their own behavior and the behavior of others. Attribution theory emphasizes how individuals interpret events and how this relates to their thinking and behavior. Attribution theory was first proposed by Fritz Heider (1958) and further developed by Edward Jones and Keith Davis (1965), Harold Kelley (1967, 1972), and Bernard Weiner (1974).

Attribution theory explains that the cause of a person choosing a behavior can come from internal dispositional attributions (individual characteristics) and external situational attributions. Internal causes tend to lead to aspects of individual behavior, something that already exists in a person, such as personal traits, abilities, self-perceptions, and motivations. Differences in the characteristics of men and women can be assumed to be an internal cause of a correlation or link between compliance with health protocols in the new normal era. Therefore, this research will raise the title "Gender Correlation with Compliance with Implementing Health Protocols in the New Normal Era." 


\section{METHOD}

The explanatory quantitative method was used as the research method in this study. Quantitative methods are research that describes or explains a problem whose results can be generalized and is considered appropriate in this study with aspects of measurement and data breadth so that the data or research results are considered representative of the entire population (Kriyantono, 2010:55). This analysis is an analysis in the form of data obtained from respondents who have been collected, then analyzed and processed using statistical theory as a problemsolving tool so that this method will provide certainty in making decisions.

By this method is intended to explain a generalization of the sample to the population or explain the correlation of differences or the influence of one variable on another. Therefore, explanatory research has the credibility to measure the causal correlation of two or more variables using inferential statistical analysis (Silalahi, 2012: 63).

The population in this study is all students studying at the top 5 universities in Riau Province released by 4ICU UniRank (world campus ranking agency) in 2021 with data on the number of students by the Higher Education Data Collection Database (PDDIKTIKEMENDIKBUD), such as: (1) Sultan
Syarif Kasim State Islamic University (UIN) Riau with 10,112 male students and 13,135 female students, bringing a total of 23,247 students. (2) University of Riau (UNRI) with 13,571 male students and 21,514 female students for a total of 35,085 students. (3) Muhammadiyah University of Riau with 5,055 male students and 4,339 female students for a total of 9,394 students. (4) Lancang Kuning University (Unilak) with 7,033 male students and 4,362 female students for a total of 11,395 students. (5) Riau Islamic University (UIR) with 17,384 male students and 13,044 female students for a total of 30,428 students.

Therefore, from the description above we can conclude that the total population in this study was 109,549 students.

The sampling technique chosen by the researcher used the Slovin formula. Then it found the number of samples obtained for this study was 399 respondents. In order for the questionnaire to be spread evenly throughout the sample criteria, a Propionate Stratified Random Sampling technique is used by sampling in heterogeneous and stratified populations by taking samples from each subpopulation that are adjusted to the number of members from each sub-population randomly. The method used is a quantitative method with data collection 
techniques using questionnaires and observation. This study using construct validity (construct validity). Testing the validity of this research instrument was carried out with the help of the SPSS 25 application/software and using the Pearson bivariate technique. Meanwhile, the instrument reliability test in this study used the Cronbach Alpha Formula technique and the SPSS 25 in windows program. The data were analyzed using the SPSS Spearman's Rank test, which states the correlation between $\mathrm{X}$ and $\mathrm{Y}$ variables. The results obtained by this study indicate a significant correlation between the Gender variable and the Health Protocol Compliance variable.

\section{RESULT AND DISCUSSION}

In general, the results of the study found that there is a significant correlation between the Gender variable and the Health Protocol Compliance variable. The presentation of data from interviews and observations will be presented and divided such as:

\section{Respondents Response to Gender Variable (X)}

Table 1. Based on gender

\begin{tabular}{|l|l|l|l|}
\hline No. & Gender/Sex & F & P (\%) \\
\hline 1 & Male & 116 & $29,1 \%$ \\
\hline 2 & Female & 283 & $70,9 \%$ \\
\hline \multicolumn{2}{|l|}{ Total } & 399 & $100 \%$ \\
\hline
\end{tabular}

Based on table 1 , it shows that the difference between the number of male and female respondents is very large. Then, this table also shows that female respondents dominate more than male respondents.

\section{Respondents Response to Health Protocol Compliance Variable (Y)}

Compliance with health protocols is a form of behavior of a person's obedience to the rules and regulations made to protect the health of themselves and others so that all parties can carry out their activities safely and adequately. In this study, researchers have distributed questionnaires to 399 respondents. The researchers wanted to see how respondents gave their responses to the statements that the researchers had given according to the variable indicators complying with the health protocol. The indicators are divided into 5: washing hands, maintaining distance, wearing masks, reducing mobility, and avoiding crowds. The results of respondents' responses to these indicators are as follows:

Table 2. Results of respondents' responses to these indicators

\begin{tabular}{lll}
\hline No & Indicator & Result \\
\hline 1 & Washing & More than half of \\
& hands & the respondents \\
& & stated that they \\
& & agreed that \\
& & respondents were \\
& & obedient to washing \\
& & their hands with \\
\hline
\end{tabular}




\begin{tabular}{|c|c|c|}
\hline No & Indicator & Result \\
\hline & & $\begin{array}{l}\text { soap or using hand } \\
\text { sanitizer before and } \\
\text { after handling } \\
\text { objects inside and } \\
\text { outside the house, } \\
\text { and more than half } \\
\text { of the respondents } \\
\text { stated that they } \\
\text { agreed that they } \\
\text { were obedient to } \\
\text { avoid touching their } \\
\text { eyes, nose, and } \\
\text { mouth before } \\
\text { washing hands }\end{array}$ \\
\hline 2 & $\begin{array}{l}\text { Maintaining } \\
\text { distance }\end{array}$ & $\begin{array}{l}\text { More than half of } \\
\text { the respondents } \\
\text { stated that they } \\
\text { agreed that the } \\
\text { respondents obeyed } \\
\text { the health protocol, } \\
\text { namely maintaining } \\
\text { a minimum distance } \\
\text { of } 1 \text { meter from } \\
\text { other people when } \\
\text { outside the house }\end{array}$ \\
\hline 3 & $\begin{array}{l}\text { Wearing } \\
\text { masks }\end{array}$ & $\begin{array}{l}\text { More than half of } \\
\text { the respondents } \\
\text { stated that they } \\
\text { strongly agree that } \\
\text { the respondent } \\
\text { complies with the } \\
\text { health protocol, } \\
\text { namely wearing a } \\
\text { mask when outside } \\
\text { the house }\end{array}$ \\
\hline 4 & $\begin{array}{l}\text { Reducing } \\
\text { mobility }\end{array}$ & $\begin{array}{l}\text { More than half of } \\
\text { the respondents } \\
\text { stated that they } \\
\text { agreed that the } \\
\text { respondents adhered } \\
\text { to the health } \\
\text { protocol, namely } \\
\text { limiting mobility } \\
\text { and interaction with } \\
\text { other people }\end{array}$ \\
\hline 5 & $\begin{array}{l}\text { Avoiding } \\
\text { crowds }\end{array}$ & $\begin{array}{l}\text { More than half of } \\
\text { the respondents } \\
\text { stated that they } \\
\text { agreed that the }\end{array}$ \\
\hline
\end{tabular}

\begin{tabular}{ll}
\hline No Indicator & Result \\
\hline & respondent \\
& complied with the \\
& health protocol, \\
& which is to stay \\
& away from crowds \\
& when outside the \\
& house \\
\hline
\end{tabular}

Furthermore, to see the dominant answer on the indicator variable complying with the health protocol (Y). Researchers combine dominant statements on each indicator and the result shows; There are five indicators on the variable that comply with the health protocol (Y) with six statements. Where, the statement item with the highest choice results is found in the indicators of washing hands and keeping a distance, with the statement "I obey to avoid touching my eyes, nose, and mouth before washing my hands." And "I obey to maintain a minimum distance of 1 meter from other people when outside the house" statement with the same frequency of answers as 264 or $66.2 \%$ of respondents. Then, the statement item with the lowest choice of results found in the indicator of wearing a mask, namely the statement "I obey to wear a mask when I am outside the house" with a frequency of 204 answers or $51.1 \%$ of respondents.

Those results are furthermore tested by Spearman Rank Correlation Test Analysis methods to test assumptions about the existence of a correlation 
between variables if the data is ordinal scale (rank).

Table 4. Spearman Rank Correlation

Results

\begin{tabular}{|c|c|c|c|c|}
\hline & & Correlatic & & \\
\hline & & & $\begin{array}{c}\text { Gend } \\
\text { er }\end{array}$ & T.Y \\
\hline $\begin{array}{l}\text { Spe } \\
\text { arm }\end{array}$ & $\begin{array}{l}\mathrm{Ge} \\
\text { nde }\end{array}$ & $\begin{array}{l}\text { Correlation } \\
\text { Coefficient }\end{array}$ & 1.000 & $\begin{array}{r}.13 \\
5^{* \star}\end{array}$ \\
\hline $\begin{array}{l}\text { an's } \\
\text { rho }\end{array}$ & $r$ & $\begin{array}{l}\text { Sig. (2- } \\
\text { tailed) }\end{array}$ & . & $\begin{array}{r}.00 \\
7\end{array}$ \\
\hline & & $\mathrm{N}$ & 399 & 399 \\
\hline & T.Y & $\begin{array}{l}\text { Correlation } \\
\text { Coefficient }\end{array}$ & $.135^{* *}$ & $\begin{array}{l}1.0 \\
00\end{array}$ \\
\hline & & $\begin{array}{l}\text { Sig. (2- } \\
\text { tailed) }\end{array}$ & .007 & . \\
\hline & & $\mathrm{N}$ & 399 & 399 \\
\hline $\begin{array}{l}{ }^{* *} . \mathrm{C} \\
\text { tailec }\end{array}$ & latio & significant & & \\
\hline
\end{tabular}

Based on the table above, the value of Sign. (2-tailed) is 0.007 and means Sig. (2-tailed) $<0.05$ then there is a significant correlation between the Gender variable and the Health Protocol Compliance variable. It was found that the correlation coefficient value was 0.135 , so it can be concluded that the level of relationship between the two variables Gender $(\mathrm{X})$ and Behavior Complying with Health Protocols (Y) had a very weak correlation.

Respondents' answers Men and women who chose to strongly agreed to comply with the health protocol are reflected in the five behavioral indicators of complying with the health protocol (Y) with six statements. Where, the statement items with the highest choice results are found on the indicators of washing hands and keeping distance, namely the statements "I obey to avoid touching my eyes, nose, and mouth before washing my hands" and "I obey to keep a distance of at least 1 meter from other people when I am in bed. outside the home" with the same frequency of answers as many as 264 or $66.2 \%$ of respondents. And, the statement item with the lowest choice of results found in the indicator of wearing a mask, namely the statement "I obey to wear a mask when I am outside the house" with a frequency of 204 answers or $51.1 \%$ of respondents.

According to White, gender is a description of the behavior patterns of men or women that are recognized in social life. Lippa said that men are aggressive, arrogant, competitive, rude, cruel, dominant, independent, and unemotional, while women are more affectionate, anxious, loving, dependent, emotional, gentle, sensitive, and submissive. The personality possessed by women seems to make women more concerned with health than men (Tambuwun et al., 2021). accordance with the explained attribution theory put forward by Robbins in (Darmawati, 2019) explaining a person's behavior caused by external or internal factors. It can be conclude that Attribution Theory is a theory that explains efforts to 
understand the causes behind other people's behavior. Behavior caused by external factors is behavior influenced by outside parties such as equipment or other people's social influences, meaning that the individual or his personality is forced to behave like this because of the situation. While internal factors are behaviors that are believed to be under control or originating from within the individual, such as personality traits, motivations, or abilities. So that gender (male and female) with different personalities or characteristics has a relationship with behavior in complying with health protocols.

\section{CONCLUSION}

Based on the results of the research described in the previous chapter, Gender Correlation with Compliance with Implementing Health Protocols in the New Normal Era are formulated in two conclusions. First, the female gender has a higher average score than the male gender. The male score is 116 , while the female student's score is 283 . It can be concluded that there are differences in the level of behavior in complying with health protocols between men and women.

Lastly, it is a significant correlation between the Gender variable and the Health Protocol Compliance variable. The correlation coefficient value is 0.135 , which concluded that the level of correlation between the two variables, Gender (X) and behavior Complying with Health Protocols (Y), has a fragile correlation.

\section{REFERENCES}

Afrianti, N., \& Rahmiati, C. (2021). Faktor-Faktor Yang Mempengaruhi Kepatuhan Masyarakat Terhadap Protokol Kesehatan Covid-19. Jurnal Ilmiah Permas: Jurnal Ilmiah STIKES Kendal Volume 11 No 1, Hal 113 - 124, Januari 2021 Sekolah Tinggi Ilmu Kesehatan Kendal

Akdon, R. (2013). Rumus dan Data dalam Aplikasi Statistika. Bandung: Alfabeta.

Albery, I. P., \& Munafo, M. (2011). Psikologi Kesehatan Panduan Lengkap dan Komprehensif Bagi Studi Psikologi Kesehatan. Cetakan I. Yogyakarta: Palmall.

Anggreni, D., \& Safitri, C. A. (2020). Hubungan Pengetahuan Remaja tentang COVID-19 dengan Kepatuhan dalam Menerapkan Protokol Kesehatan di Masa New Normal. Hospital Majapahit, 12(2), 134-142.

Baron, Robert A. \& Byrne, Donn. (2004). Psikologi Sosial. Jakarta: Erlangga

Bungin, B. (2011). Metode Penelitian Kuantitatif. Jakarta: Kencana Pred ana Media Group.

CNN Indonesia. (2020). BPS: 17 Persen Warga Percaya Tak Bakal Tertular Covid-19.

https://www.cnnindonesia.com/nasi onal/20200928203046-20551995/bps-17-persen-wargapercaya-tak-bakal-tertular-covid-19 
Darmawati. (2019). Pengaruh Sikap, Norma Subjektif, Dan Persepsi Kontrol Perilaku Terhadap Perilaku Berwirausaha Dengan Niat Berwirausaha Sebagai Variabel Intervening Pada Mahasiswa Fakultas Ekonomi Dan Bisnis Islam Uin Alauddin Makassar. Journal of Chemical Information and Modeling, 19-20.

Dinas Kesehatan Provinsi Riau. (2021). Riau Tanggap Covid-19. https://corona.riau.go.id/

Fishbein, M, \& Ajzen, I. (1975). Belief, Attitude, Intention, and Behavior: An Introduction to Theory and Research, Reading, MA: AddisonWesley.

Ghufron, M. N., \& Risnawita, S. R. (2010). Teori- Teori Psikologi. Yogyakarta: Ar- Ruzz Media

Hartati, C. (2020). Pengaruh Konten Channel Youtube Jurnalrisa Terhadap Opini Subscriber Tentang Konten Mist. Jom Fisip, Universitas Riau, 7(2). 1-11.

https://www.kemkes.go.id/Protokol-

Kesehatan

Istiatin, et al. (2021). Meningkatkan Perilaku Mawas Diri Pada Era New Normal Masyarakat Jurangjero, Karangmalang, Sragen (KKN Tematik Uniba 2020). Jurnal Budimas, 3(1).

Kriyantono, R. (2009). Teknik Praktis

Riset Komunikasi. Jakarta : Kencana Prenada Media Grub.

Kriyantono, R. (2014). Teknik Praktis

Riset Komunikasi. Jakarta:

Prenadamedia Group.

Mustafa, H. (2011). Manusia Dalam Perspektif Psikologi Sosial. Jurnal Administrasi Bisnis, 7(2). 143-156.
Bandung: Universitas Katolik Parahyangan

Nurhayati, S. R., \& Sugiyanto. (2005). Atribusi dalam Rumah Tangga, Kesadaran Terhadap Kesetaraan Gender, dan Strategi Menghadapi Masalah pada Perempuan Korban Kekerasan Dalam Rumah Tangga. Jurnal Psikologi, 32(1). 34-46.

Rosady, R. (2004). Metode Penelitian Public Relations dan Komunikasi. Jakarta: Raja Grafindo Persada.

Santi, M. et al. (2021). Tentang Protokol Kesehatan Pencegahan Covid-19 Skripsi Tentang Protokol Kesehatan Pencegahan.

Sarwono, Sarlito W dan Meinarno, EA. (2009). Psikologi Sosial. Jakarta: Salemba Humanika.

Sheli, R. (2011). Faktor-faktor psikologi yang Mempengaruhi Intensi Merokok pada Remaja. Skripsi. Fakultas Psikologi: Universitas Islam Negeri Syarif Hidayatullah.

Siregar, E. W. (2020). Efektivitas Komunikasi Aplikasi Online Linkedln Sebagai Media Informasi Lowongan Kerja Bagi Alumni Universitas Riau. Jom Fisip, Universitas Riau, 7(2), 1-8.

Sugiarto. (2003). Teknik Sampling. Jakarta: Gramedia Pustaka Utama.

Tambuwun, A. A. et al. (2021). Hubungan Karakteristik Individu Dengan Kepatuhan Berobat Pada Penderita Hipertensi Di Puskesmas Wori Kabupaten Minahasa Utara. Kesehatan Masyarakat, 10(4), 112121. 